\title{
Advancing environmental mitigation on the Bretagne-Pays de la Loire railway, France
}

\section{Marion Aubrat}

Sustainability Engineer, Sustainability Department, Eiffage, Vélizy-

Villacoublay, France (corresponding author: marion.aubrat@eiffage.com)
Joachim Lemeri

Head of Sustainable Engineering, Eiffage, Vélizy-Villacoublay, France

The new $182 \mathrm{~km}$ Bretagne-Pays de la Loire high-speed rail line in France has pioneered the use of an environmental mitigation hierarchy, leading to significant sustainability benefits. As this paper describes, the project has gone beyond regulatory obligations and contractual provisions for sustainability, particularly regarding biodiversity and carbon dioxide emissions. It has opened up a more sustainable way of conceiving and building transport infrastructure, with extensive collaboration, innovative organisation, technical and operational tools and a longterm, efficiency-based offsetting approach. Early adoption of the mitigation hierarchy principle on this project enabled the worksite footprint to be reduced by $8 \%$ and avoided the emission of $4 \cdot 5 \%$ of greenhouse gases associated with the line's construction. It also accounted for biological cycles during work planning and secured the ecological offsetting sites before construction started, which in turn ensured their functionality over a 20-year period to ensure no net loss of biodiversity.

\section{Introduction}

The new French Bretagne-Pays de la Loire high-speed railway line, called BPL, is a $€ 3$ billion investment project that extends the Atlantic Paris-Le Mans high-speed railway from the city of Le Mans to the city of Rennes (Figure 1), shortening the Paris-Rennes journey by $37 \mathrm{~min}$ as of the entry into operation date in July 2017.

The environmental mitigation hierarchy, with its three methodological steps - avoid, minimise and offset the impacts on the environment - has been strictly followed, making the BPL project a textbook sustainable case in Europe, particularly regarding biodiversity and carbon dioxide $\left(\mathrm{CO}_{2}\right)$ emission issues. As this project provided an opportunity for many 'firsts' in France, a voluntary agreement was concluded between the public developer (Société nationale des chemins de fer français (SNCF Réseau)) and the constructor (Eiffage) to trial the implementation of sustainable development on the project beyond regulatory obligations and contractual provisions.

The mitigation hierarchy implementation in this project enabled improvement of the company's internal practices and good practices in France more generally.

The applied actions, at the organisational, technical and operational levels, pave the way to a more sustainable way of conceiving and building transport infrastructures: strong environmental commitments at the top echelon; transverse collaboration improvement; local stakeholders' involvement; sensitisation to environmental issues at every level; integration of biodiversity issues at every stage of the project; development of innovative tools to lever carbon dioxide footprint reduction; limitation of offset surface and monitoring of sustainable actions; and implementation of a long-term efficiencybased offsetting approach.
This paper presents BPL's successful experimentations, as a step towards implementing the vision whereby land planning projects can help to plan the land 'carefully'.

\section{Mitigation hierarchy as guiding principle}

The BPL project has been part of the French national policy framework for high-speed lines (HSLs) since 1992.

The design of this $182 \mathrm{~km}$ long infrastructure $(214 \mathrm{~km}$ with connecting links) involved various phases from 1994 to 2006, during which the public developer, SNCF Réseau (formerly 'Réseau Ferré de France'), ensured that environmental issues were taken into account at the earliest possible stage. The final design enabled a satisfactory compromise to be reached between technical and financial constraints, in line with the interests of the affected communities and the natural environment (Figure 2), avoiding all hotspots for protected biodiversity (no Natura 2000 sites affected), major wildlife corridors and all but one of the natural zones of ecological interest for fauna and flora (ZNIEFF).

On 26 October 2007, a French government decree declared this project to be of public utility and urgent need, followed in December 2008 by a European competitive tendering process launched by SNCF Réseau for a public-private partnership (PPP).

Eiffage Rail Express (Ere), a wholly owned subsidiary of Eiffage, a French construction company, was awarded the PPP for prefinancing, design, building, maintenance and regeneration of the BPL until 2036, the date by which SNCF Réseau will have a fully modernised line.

From 2011 to 2012, Ere and the engineering companies redefined the initial environmental design with the authorities, the local non-governmental organisations and the scientific 


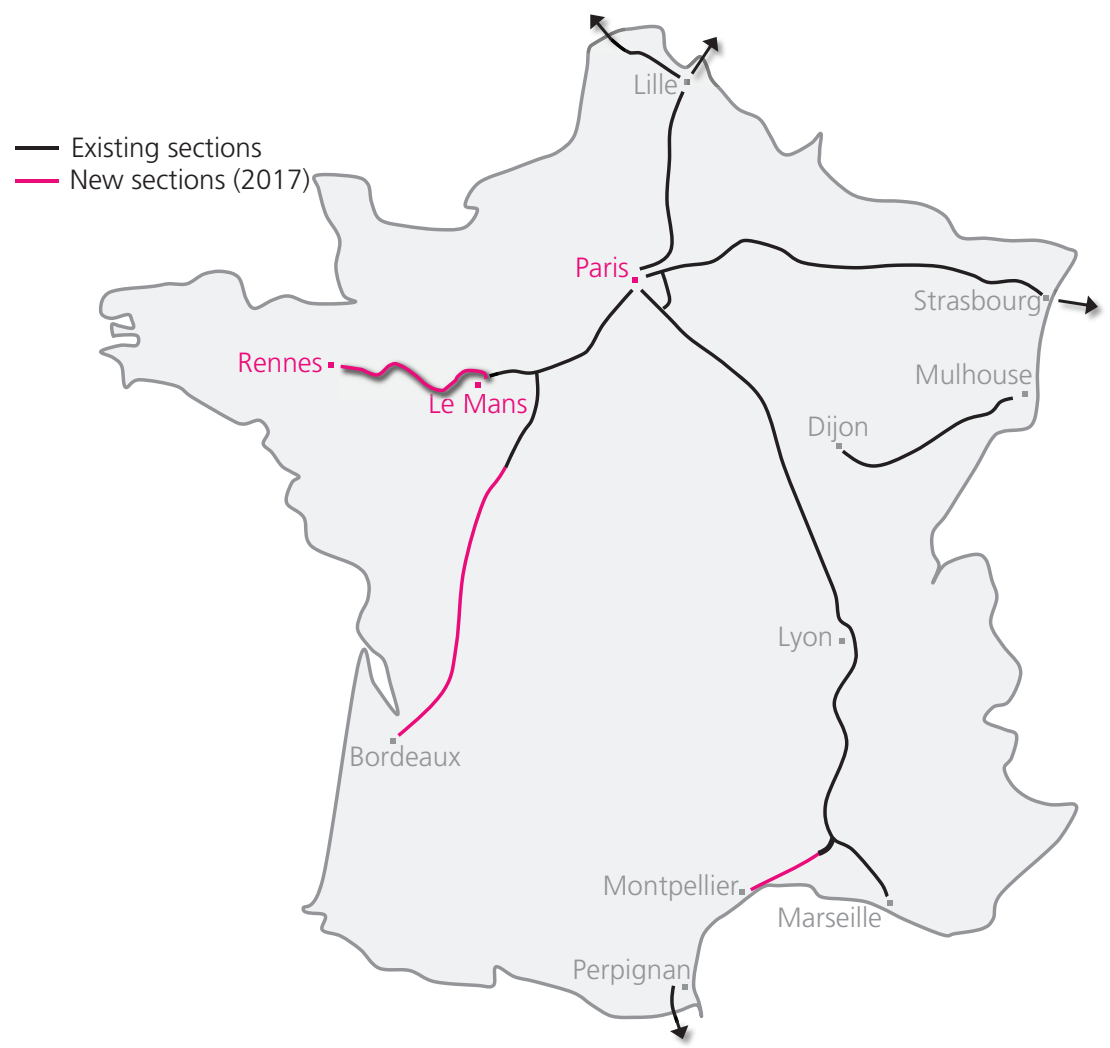

Figure 1. Diagram of high-speed lines (HSLs) network in France at the end of 2017

community, following strictly the principles of the international environmental mitigation hierarchy standard (BBOP, 2012a) - that is, 'A', avoid the effects; then ' $M$ ', minimise them on the ground; and ' $\mathrm{O}$ ', offset the residual impacts.

During the beginning of the work phase in 2012, a voluntary agreement was concluded between SNCF Réseau and Ere to formalise the common will to experiment with the operational implementation of sustainable development in this project, beyond regulatory obligations or contractual provisions. This upstream voluntary engagement towards sustainability allowed the implementation of human and financial resources on this subject from the very beginning of the project.

Besides this voluntary agreement, a specific sustainable development organisation has been established on all operational levels, gathering around 30 individuals (at the top of activities), including both on-site and off-site environment managers. Some of them take part in the 'BPL sustainable committee', which, by bringing together project managers several times a year, enables sharing of experiences and feedback, as well as cross-managerial, cross-technical and cross-operational points of view on strategic topics such as public consultations, environmental permits, land acquisitions and biodiversity offset, in order to achieve the best compromise in line with the sustainability objectives.
Both the upstream engagement and the innovative organisation allowed an effective implementation of the mitigation hierarchy approach from the design period to the end of works in 2015 , particularly concerning carbon dioxide footprint and biodiversity issues.

\section{Avoidance by means of anticipation}

\subsection{Route design and technical adaptations}

As the preferred bidder for the PPP contract in April 2011, Ere launched targeted environmental assessments to improve its knowledge of the territory and to anticipate the potential impacts, particularly on biodiversity. These new data allowed route alterations to be proposed, one of which had a significantly reduced impact on the only ZNIEFF affected by the project (Figure 2).

The ecological transparency of the new line was systematically interrogated at points of conflict between the infrastructure and the ecological continuities (wildlife and hydraulic corridors, known as 'green and blue frameworks' in France, recently identified in each region). In total, 275 structures were established to guarantee the ecological transparency of the infrastructure.

The environmental permits were obtained by means of continuous discussions with local authorities: methodologies and inputs were 


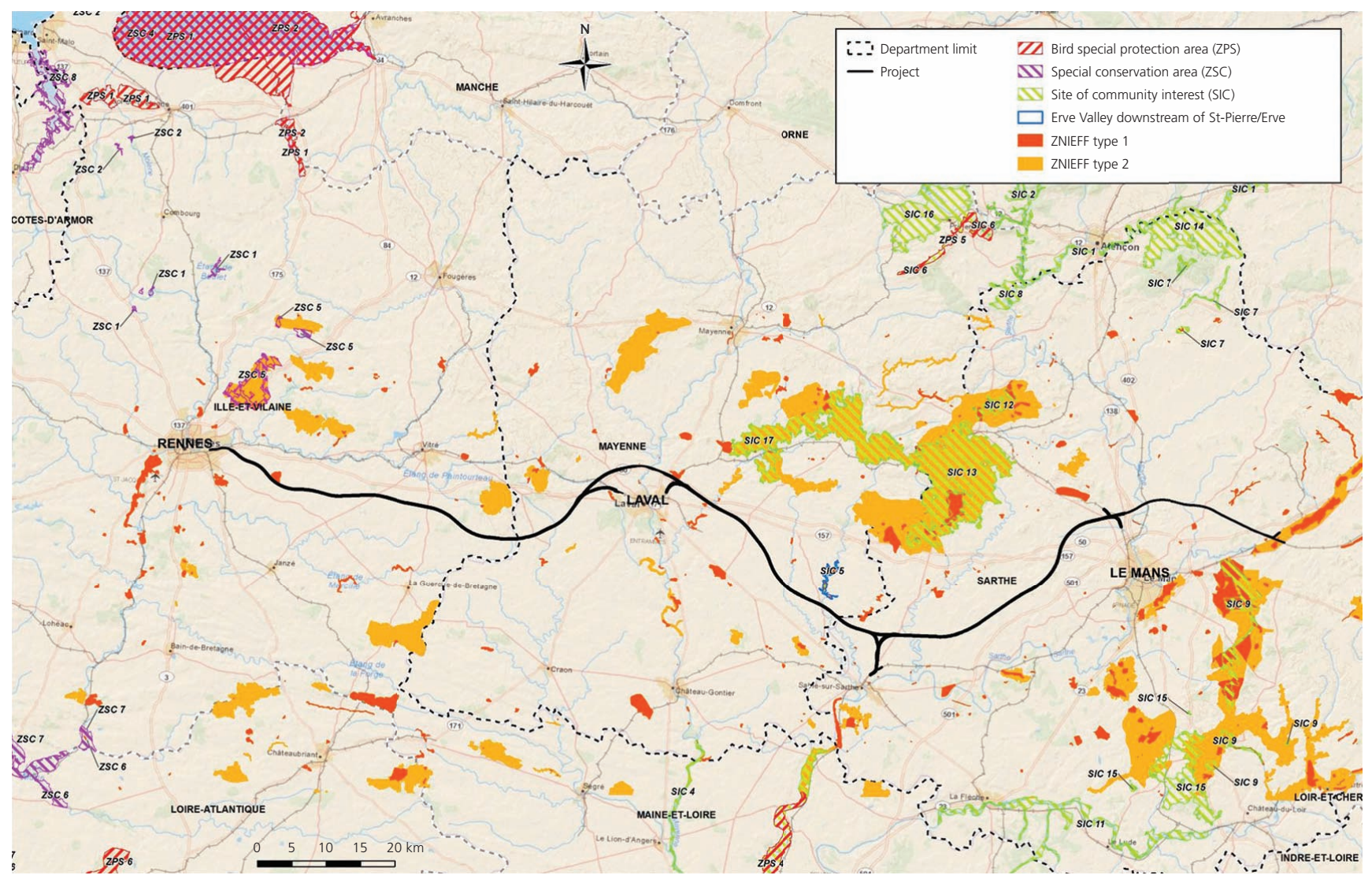

Figure 2. The $214 \mathrm{~km}$ route of the high-speed rail line between Le Mans and Rennes avoiding the main ecological areas of interest. (c) Ere

shared, devised and approved during technical committee meetings bringing together design teams, local authorities and experts.

Ecological surveys were also a subject of critical revision by independent and recognised specialists regarding protocols, proposed impact reduction and offsetting measures.

Finally, designers made a consistent effort to limit the work footprint, in particular on sensitive sites such as wetlands, woodlands and natural areas: in total, a reduction of 190 ha on rural lands and 10 ha on woodlands was obtained, avoiding the effects on around $8 \%$ of the initial perimeter.

\subsection{Carbon dioxide budgeting as a motivation to contain the emissions}

The carbon dioxide debt, due to the emissions of an HSL's construction, takes 30 years of operation (SNCF, 2010) to be repaid. The construction period is therefore critical for carbon dioxide emissions.

During the final offer, a forecasted carbon dioxide assessment was established on the construction phase, predicting an average of
6620 tonnes carbon dioxide equivalent $\left(\mathrm{tCO}_{2} \mathrm{e}\right)$ (or 1805 tonnes carbon equivalent (tCe)) per kilometre of HSL.

In order to control the project's actual emissions throughout the construction process, it was decided, for the first time on a railway project, that the carbon dioxide footprint would be updated annually with the effective quantities. Appraised by an independent expert (Objectif Carbone), this annual carbon dioxide calculation process is transparent and provides the public developer with a reliable phase-by-phase data set for the actual carbon dioxide emissions of the HSL's construction.

From an operational point of view, this reporting process triggered consistent efforts to contain the project emissions, improved internal knowledge about ecological performances of products and processes and raised awareness internally and externally (subcontractors and suppliers) on carbon dioxide issues.

At the end of the works, the project's final carbon dioxide report displays a reduction in carbon dioxide emissions by $4.5 \%$ compared to the emissions forecast during the final offer. This represents an avoidance of more than $53000 \mathrm{tCO}_{2} \mathrm{e}$, breaking 
down the emissions of a kilometre of HSL construction to a little less than $6350 \mathrm{tCO}_{2} \mathrm{e}$ (or $1725 \mathrm{tCe}$ ).

\subsection{Team training to prevent the propagation of invasive alien species}

Earthworks are conducive to the spreading of alien species, whether animals, plants, fungi or microorganisms, that can become invasive and have serious adverse effects on biodiversity and related ecosystem services, as well as other social and economic impacts. Some 12000 species in the environment of the $\mathrm{EU}$ and other European countries are alien, of which roughly $10-15 \%$ are estimated to be invasive (Regulation (EU) No 1143/ 2014 (EC, 2014)).

On the BPL project, the invasive alien species issue concerned various plants: Japanese knotweed (Fallopia japonica), knotgrass (Paspalum distichum), pampas grass (Cortaderia selloana), Himalayan balsam (Impatiens glandulifera), parrot's feather water milfoil (Myriophyllum aquaticum), New Zealand pygmyweed (Crassula helmsii) and so on. To prevent their spreading and associated adverse effects, strict management was undertaken with prior training by academics from the University of Rennes. All concerned spots observed were mapped, and contaminated areas were closed off using wooden stakes and orange mesh and identified with an information board. Appropriate treatment was implemented in line with the reproductive strategy of the invasive plants present, and environmental monitoring took place during the construction phase.

\section{Minimising impacts: a multidisciplinary approach at the core of the project}

\subsection{No impact minimisation without strong} environmental commitments and an action plan

Stakeholders needed guarantees regarding the implementation of the environmental commitments taken during the design phase (monitoring compliance). It was thus essential that these were supported by all those involved in the project. To this purpose, several documents were established to translate strategic will into operational actions.

The environmental commitments were transcribed in technical documents and agreements with subcontractors involved in each work section, by means of environmental protection notices produced by project management, which explained the main environmental issues in the surroundings and the priority principles to respect. Sub-contractors subsequently converted these commitments into specific actions within their environmental protection plans (EPPs).

Furthermore, a strategic sustainability actions plan (PASDD in French), detailing strategic actions to implement in the project, was set off to strengthen Eiffage's sustainability policy on the project. Developed by all the project entities (management, design and construction teams), the actions concern both the construction phase and the operating phase and respond to three strategic lines.
The first line is to control and limit ecological consequences, by making operational ecological documents available, assessing the efficiency of offset measures, reducing the impact on resources and taking into account biological cycles for work planning.

The second line concerns respect for the human environment: by limiting the traffic of heavy vehicles, limiting exposure of workers and neighbours to noise, reducing the final consumption of agricultural land and favouring local employment and local businesses.

The last strategic line is to be an active and responsible sustainable actor on the economic and social plan: by favouring consultation at every project stage, setting up a responsible procurement policy and favouring transparency with communication and reporting.

Each action is precisely detailed into targets, and key project indicators (KPIs) have been determined, enabling clear management and monitoring of the actions' achievement. For example, one of the targets of the action 'taking into account biological cycles for work planning' is to provide the environment managers and work teams with scientifically approved instruction sheets for each intervention in an ecologically sensitive area. The chosen KPI here is the percentage of sensitive areas covered by those instruction sheets. KPIs were reported quarterly and communicated to the project directors, the sustainable committee and the client.

\subsection{Carbon dioxide fund for footprint reduction}

To go further in its carbon dioxide budgeting, Eiffage has also allowed experimentation, with an innovative sustainable solution, the carbon dioxide fund, instated for the first time in the civil works sector (UIC, 2016) on BPL.

This arbitration process and financial tool enables the reduction of the project carbon dioxide footprint through technical optimisations (examples in Table 1), which are very constrained, mainly because of the strict technical norms and the huge proportion of material-based emissions ( $83 \%$ of total emissions according to the forecast carbon dioxide footprint).

Table 1. Examples of carbon dioxide-saving solutions financed by the carbon dioxide fund on BPL

\begin{tabular}{lc}
$\begin{array}{l}\text { Example of solution financed by the } \\
\text { carbon dioxide fund }\end{array}$ & $\begin{array}{c}\text { Carbon dioxide } \\
\text { gain: } \mathrm{tCO}_{2} \mathrm{e}\end{array}$ \\
\hline $\begin{array}{l}\text { Replacement of a reinforced-concrete wall } \\
\text { with a reinforced-earth solution }\end{array}$ & 125 \\
Reduction (optimisation) in the length of a \\
rail bridge
\end{tabular}


Established during both the civil work phase and the railway work phase (2012-2015), this tool enabled

- identification of technical solutions (process, materials) capable of reducing the carbon dioxide impact of a construction site, according to the price of avoided tonnes of carbon dioxide parameter

- explanation of the set-up of some highly emitting technical solutions by showing the absence of a replacement sustainable solution at a reasonable cost compared to the price of avoided tonnes of carbon dioxide

- arbitration and in the end financing of solutions eligible through the price of avoided tonnes of carbon dioxide $\left(\mathrm{tCO}_{2} \mathrm{e}\right.$ saved) within the limits of the available fund.

To settle this process in the economic reality of the market, a budget of $€ 6$ million, allocated to the tool, was defined in advance and integrated in the cost investment of the project. The fund enabled the avoidance of approximately $16000 \mathrm{tCO}_{2} \mathrm{e}-$ that is, the emissions caused by the construction of more than $2.5 \mathrm{~km}$ of highspeed railway, or even the emissions generated by the famous annual 'Paris-Dakar' rally. This initiative represents a third of the project's global effort to reduce carbon dioxide emissions.

The estimated average cost of tonnes carbon dioxide equivalent saved is around $€ 350$, showcasing that in such a strictly regulated environment, construction teams were faced with a big task to change construction regulations and habits. Even though this experiment is not cost-effective (which was not the main aim), the fund is a real success as, with a modest share of the construction cost, it represented a significant lever to mitigate the carbon dioxide content of the civil engineering works.

This method was approved by the French governmental energy agency (Agence de l'Environnement et de la Maîtrise de l'Énergie) and was the subject of a paper in 2014. It was also highlighted in 2016 by the International Union of Railways in a publication about the carbon dioxide footprint of railway infrastructures (UIC, 2016).

\subsection{Diversity of on-site measures for biodiversity protection}

On-site, during construction, numerous measures to minimise impacts were implemented.

To limit direct impact on biodiversity, the biological cycles of plant and animal species were taken into account when planning works on sensitive sites. For each sensitive area, experts provided instructions and sensitised work teams before enabling works: definition of a deforestation protocol for clearance operations in autumn to reduce the impact on suitable habitats for otters, the European beaver, the Eurasian and Miller's water shrew and dormice; pond management according to amphibian breeding periods; and so on. Those instructions were reported in the EPP and assessed by the environment managers. When it was not possible to adapt the construction schedule to biological cycles, accredited experts verified the presence or absence of the species on-site. If the species were present, a species transfer solution was envisaged.

Species translocations were designed and mostly conducted by entomologists from the national forestry agency (Office national des forêts (ONF)). For punctual egg translocations away from ponds, accredited experts were solicited. For plant species, the wild daffodil (Narcissus pseudonarcissus L.), the soft hornwort (Ceratophyllum submersum), the floating water plantain (Luronium natans L.) and the narrow-leaved water dropwort (Oenanthe silaifolia) were transferred with their substrate into host sites. For amphibians and insects, 25 translocations, representing 9000 specimens from 14 different species, were undertaken, including the transfer of the hermit beetle (Osmoderma eremita) with its fertile environment from fallen trees to pre-identified host trees.

The HSL route crosses many watercourses, many of them contributing to hydraulic ecological continuities, not only through water but also through riparian vegetation. To assist the movement of terrestrial and aquatic fauna beneath structures, flow modification and renaturation of 108 watercourses were implemented (Figure 3), combining compliance with the technical standards for a rail line with environmental engineering. Therefore, according to the ecological transparency needed for fish, small mammals, wild mammals and chiropterans, environmental engineering orientated the crossing structure design towards a specific type: viaduct, structure stepping over the minor bed of the river with a bench (Figure 4), pipes and so on.

\subsection{Immediate measures, between reduction and compensation}

In France, because of the complexity of the sequencing procedure, compensation has always been carried out after (or even long after) impact occurrence, leading to a net loss of biodiversity (Quétier et al., 2014) and even sometimes to species migration, which may lead to reassessment of the relevance of some wildlife structures (ECDGT, 2000).

Before BPL, between 2008 and 2010, Eiffage built the A65 motorway and piloted the biggest offset programme in France, with 1400 ha of offsetting surfaces (IUCN, 2010). Because the offsetting principles were introduced in national legislation by the 'Grenelle de l'Environnement' momentum at the very beginning of the construction, significant consequences followed (Eiffage, 2014): a 6-months delay to start the works and huge financial losses due to demobilisation of personnel and equipment. Some offsetting measures were implemented only 3-4 years after the impact.

This painful experience highlighted the challenge of risk management of biodiversity issues. On BPL, to anticipate this issue regarding pond biodiversity compensation and generate a biodiversity gain earlier on, as early as 2012 , construction teams created 78 immediate compensation ponds (Figure 5) in the 
Engineering Sustainability

Volume 171 Issue ES8
Advancing environmental mitigation on the Bretagne-Pays de la Loire railway,

France

Aubrat and Lemeri

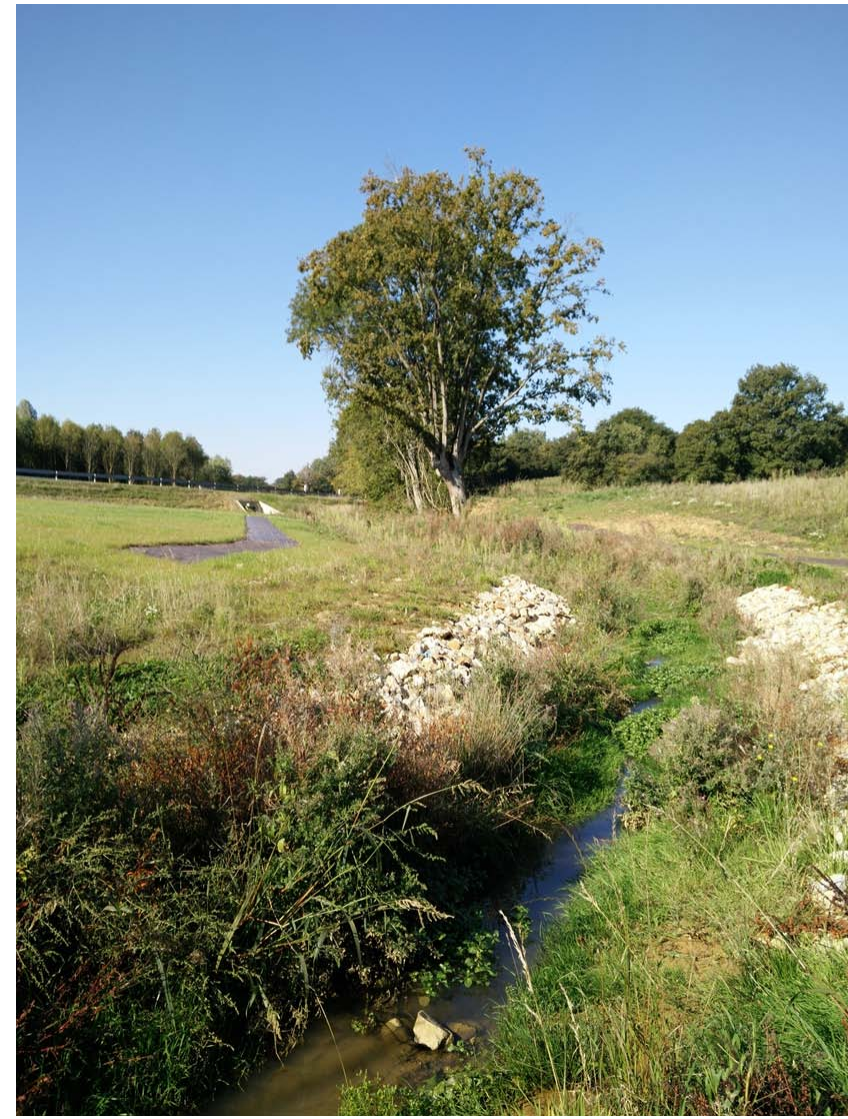

Figure 3. Creation of several flow profiles through the use of stones, wood, curves and river vegetation arrangements. (C) Eiffage

vicinity of ponds affected by the project, before these were filled in. Their functionality is subject to monitoring for 5 years after their construction: water level, plant growth, presence of species

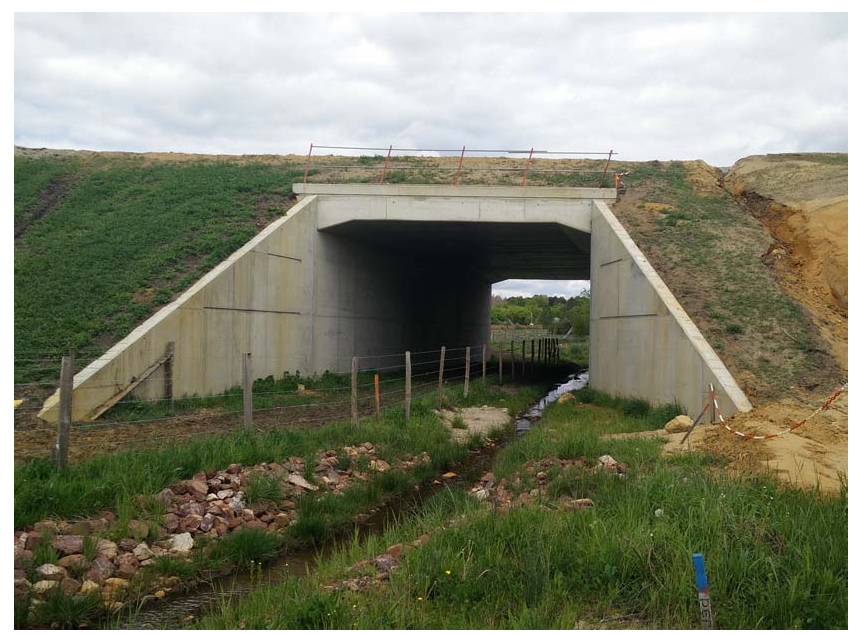

Figure 4. Mixed-use crossing structure, witness of the integration of wildlife and hydraulic corridors in BPL design. (c) Eiffage

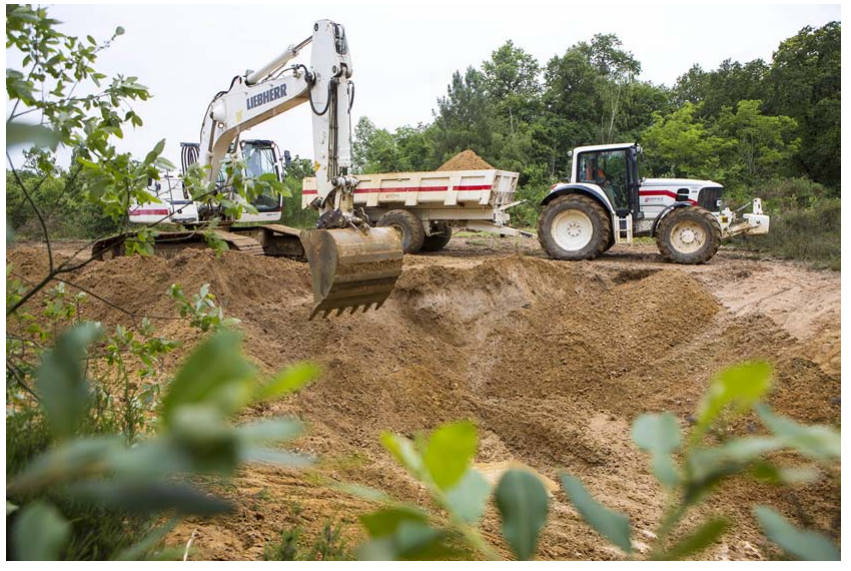

Figure 5. Compensation pond during excavation. (c) Gaël Arnaud/ Eiffage picture library

and the 'environmental DNA' measure, a new methodology for ecological surveying (Herder et al., 2014).

This anticipation permitted more than $25 \%$ of associated compensation to be instated even before the impact and provided a chance for the offset to generate a biodiversity gain.

\section{Biodiversity offsetting, a project within the project to achieve no net loss}

\subsection{Fungibility principle, a lever to limit offset total} surface

Upstream reflection on the design and works on the BPL project enabled negative impacts to be avoided/minimised. Nevertheless, some residual impacts remain, particularly in terms of wetlands and natural habitats. Offsetting these residual impacts is a strategic issue for such a linear project and has been forecast since the design stage.

It has resulted in the development or restoration of natural habitats and, subsequently, the implementation of long-term management measures by means of agreements with various stakeholders (farmers, property owners, local authorities). The objective is to achieve no net loss of biodiversity within 20 years and if possible a net gain of biodiversity, in accordance with the BBOP no net loss and loss-gain calculation paper (BBOP, 2012b) and the IUCN draft biodiversity offset policy (IUCN, 2016). This is a pioneer approach in France after the Grenelle de l'Environnement momentum.

Regarding BPL, three regulatory processes involved biodiversity offsets, representing a theoretical ecological debt with a total area of 920 ha, including

- 252 ha for wetlands, watercourses and ponds (RF, 2006)

- 454 ha for protected plant and animal species (protected species regulation)

- 214 ha for afforestation (forest regulation). 


\section{Principle 1}

Fungibility: the same measure recognised under several impacts

\section{Fungibility of compensation}

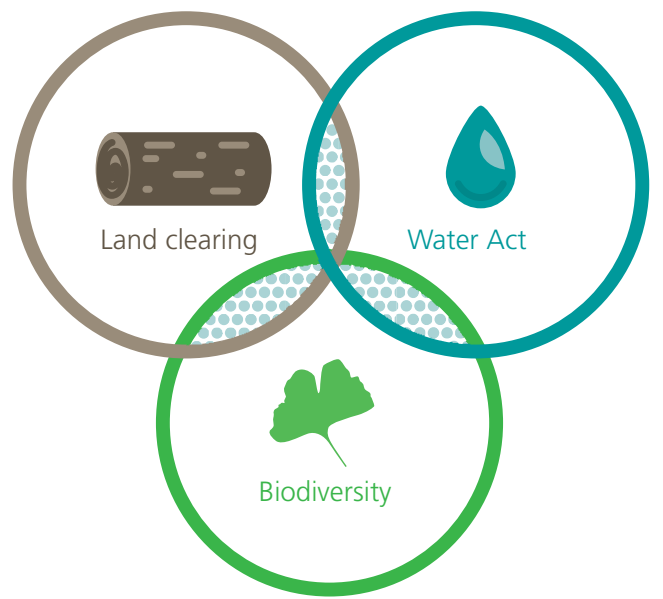

Principle 2

Property optimisation: multiplication of environmental measures on the same site

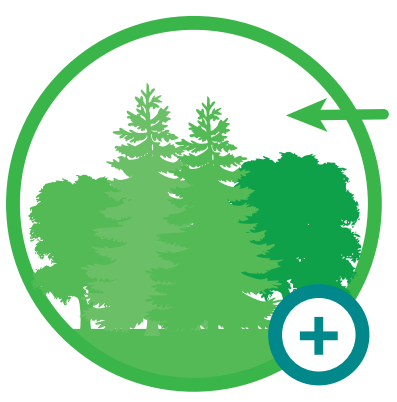

Tree planting, favourable for bats, birds and insects

Figure 6. The fungibility principles, applied on the BLP project. (C) Eiffage

The total offset area is considerable compared to the 2000 ha of total land consumption of the project, but one of the strengths of the BPL project is that it implemented for the first time the principle of the fungibility of offsetting areas (Figure 6). Approved by public authority permits in July 2012, the fungibility principle enables the same piece of land to be used for the benefit of different offsetting schemes. The following are examples.

- Riverside vegetation can provide both a habitat for semiaquatic mammals and play a part in projects for the renaturation of watercourses.

- Afforestation undertaken to offset land clearance may also be recognised as compensation for the impact on bat habitats.

Currently, offset sites represent a total area of 816 ha, $23 \%$ of which are pooled (188 ha) thanks to this principle. The theoretical offset surface is therefore of a little more than 1000 ha $(816+$ 188), allowing a reduction of the surface of land selected for offsetting purpose while exceeding the compensation goals.

Furthermore, the responsibility of Ere, the owner, towards offset implementation, ensures offset securing until the end of the PPP contract in 2036 .

\subsection{Offsetting, a long-term process}

It is important to remember the decisive role played by consultation with all the stakeholders in this process: government agencies, local authorities, experts, ecological associations, farmers' representatives and residents.

The methodology comprises three stages.
Stage 1 consists of seeking offset sites as close as possible to the impact (BBOP, 2013). Undertaken with the support of the ONF between 2012 and 2014, site seeking resulted in various sites being identified, predominantly agricultural and forestry lands impacted by the project (apart from direct project boundaries). Collaborative work with the surveyors in charge of land development, and with land use and rural settlement companies, enabled plots of land intended for offset measures to be identified. For each offset site, a biodiversity management and maintenance plan (BMMP), detailing the extent of planned ecological works and the expected benefit for biodiversity, was drawn up and submitted to local authorities for approval.

The synergy with land development enabled good land securing for offset measures of approximately $80 \%$ of the total offset area to be achieved, thereby facilitating the long-term monitoring and management of sites. Where the land acquisition was not possible, partnership agreement and actions were undertaken with third parties. A total of 240 offset sites enables BPL's ecological debt to be paid off, theoretically.

Stage 2 consists of carrying out the ecological works with a dedicated restoration operator (Aronson and Alexander, 2013). Following a consultation on the implementation, upkeep, monitoring and coordination of the network of offset sites for 20 years according to the sites' BMMP, Ere awarded this contract to a local consortium led by Dervenn, a regional environmental engineering operator.

Preliminary operations (topography, land survey) began in autumn of 2014: planting (Figure 7), tree pruning, pollarding and wetland dewatering. The environmental engineering operations took place between November 2014 and December 2016, with regular site 
Advancing environmental mitigation on the Bretagne-Pays de la Loire railway,

France

Aubrat and Lemeri

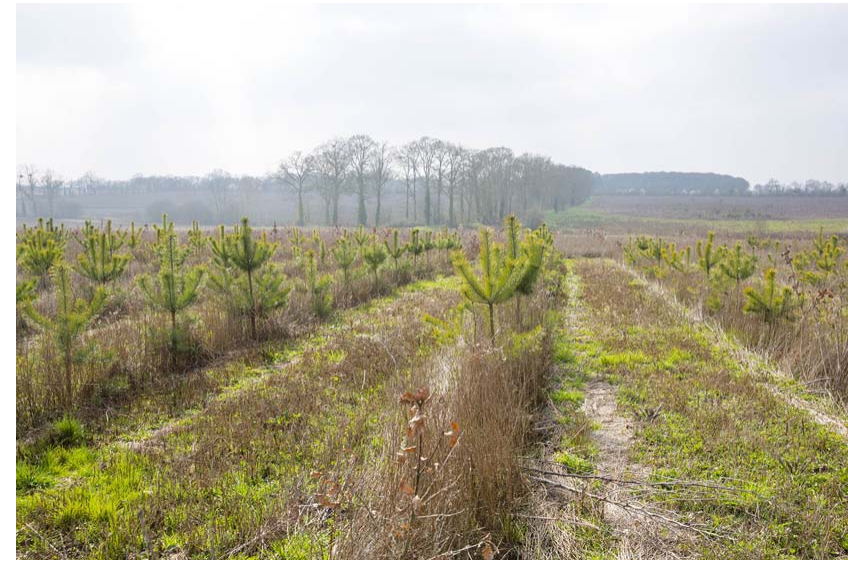

Figure 7. Tree planting, an offsetting measure. () Gaël Arnaud/ Eiffage picture library

visits with environmental authorities enabling validation of the different types of works along the way, and a final reception by Eiffage before May 2017 - that is, the delivery of the line.

By the end of 2016, work had been carried out or completed on $100 \%$ of sites. The BPL biodiversity offset is now a real offset on ground which will grow and generate ecological gains. It is remarkable that offset works were finished before the project was commissioned.

Stage 3 consists of the long-term management of offset sites. The management of the future offset areas has been planned with land users, mainly farmers in this region, meaning that specifications have been thought through with the agricultural sector, local authorities and local biodiversity specialists, in order to define practices that comply with the ecological requirements. Offset sites compatible with farming were proposed for cultivation to farmers, for one symbolic euro, in exchange for their engagement to comply with specific agricultural practices (a win-win approach). Some management measures for wetland areas are, for example, the preservation of landscape structures and the prohibition of chemical weeding.

Currently, 191 offset sites have been rented to local farmers. This is the first time in France that biodiversity compensation has combined in such proportions ecological and socio-economical functions, demonstrating the relevance of a new sustainable territorial approach which reconciles rural activities and ecological preservation.

Until 2036, those sites will form the subject of maintenance operations (mowing, dredging etc.), verification of compliance with the agricultural practices and scientific monitoring to check that ecological targets are being met to confirm no net loss of biodiversity. The scientific monitoring protocol for all the species and natural habitats offset has been drawn up in consultation with experts and the authorities (see Table 2).

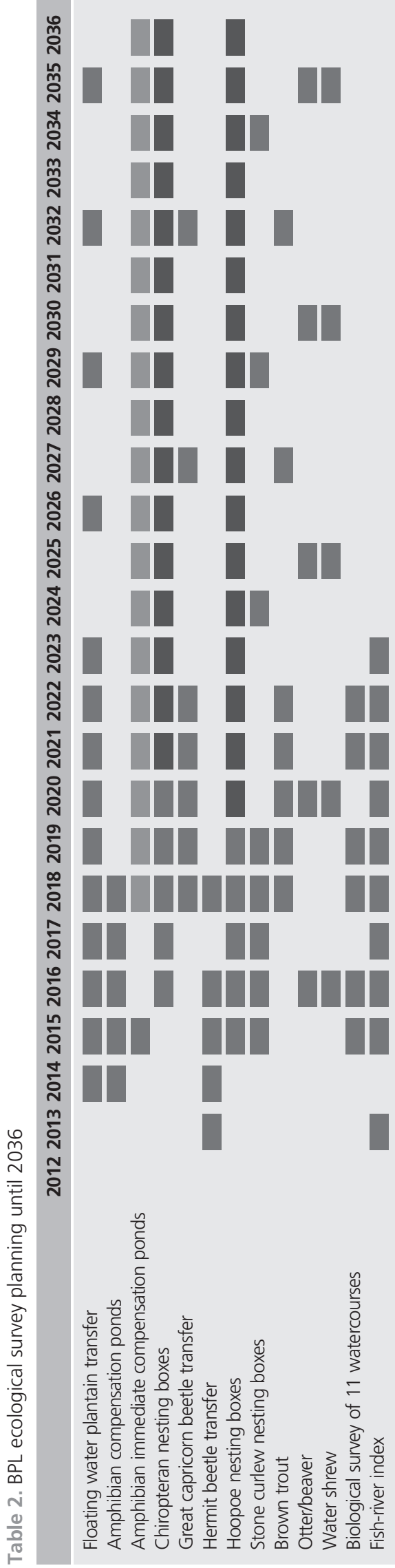


Advancing environmental mitigation on the Bretagne-Pays de la Loire railway,

France

Aubrat and Lemeri

\section{Conclusion}

In the context of the commissioning of around $600 \mathrm{~km}$ of new HSLs in 2017 in France (SNCF Réseau, 2017), the BPL line presents relevant feedback for mitigation hierarchy application.

The establishment of a voluntary agreement at the highest level of the organisation, shared internally and with every involved actor, permitted a new design process to bloom: more inclusive, involving more transverse collaboration, more sustainable and more vigilant to the functionality of landscape ecology.

Those successful experimentations, concerning carbon dioxide as well as biodiversity issues, permitted enhancement of French practices compared to technical and regulatory standards in the railway sector.

An annual carbon dioxide assessment has been settled, combined with a carbon dioxide fund to go further and promote new sustainable ways of conceiving and building railway infrastructures.

As for biodiversity, the integration of species' biodiversity cycles for work planning, the anticipation of offset land acquisition and the choice of a unique global offset operator for 20 years (without requesting offset banks) are new practices in France and in Europe.

This experience can inspire some future European projects for more sustainable land planning.

\section{REFERENCES}

Aronson J and Alexander S (2013) Ecosystem restoration is now a global priority: time to roll up our sleeves. Restoration Ecology 21(3): 293-296.

BBOP (Business and Biodiversity Offsets Programme) (2012a) Standard on Biodiversity Offsets. BBOP, Washington, DC, USA. See http://bbop. forest-trends.org/guidelines/Standard.pdf (accessed 31/07/2017).

BBOP (2012b) Resource Paper: No Net Loss and Loss-Gain Calculations in Biodiversity Offsets. BBOP, Washington, DC, USA. See http://www. forest-trends.org/documents/files/doc_3103.pdf (accessed 31/07/2017).

BBOP (2013) To No Net Loss and Beyond: an Overview of the Business and Biodiversity Offsets Programme (BBOP). BBOP, Washington, DC, USA. See http://www.forest-trends.org/documents/files/doc_3319. pdf (accessed 31/07/2017).

EC (European Community) (2014) Regulation (EU) No 1143/2014 of the European Parliament and of the Council of 22 October 2014 on the prevention and management of the introduction and spread of invasive alien species. Official Journal of the European Communities L317/35. See http://eur-lex.europa.eu/legal-content/EN/TXT/PDF/? uri=CELEX:32014R1143\&from=FR (accessed 31/07/2017).

ECDGT (European Commission Directorate General Transport) (2000) The Effect of Linear Infrastructures on Habitat Fragmentation. Technical and Information Services on National Roads, Budapest, Hungary. See https://cordis.europa.eu/pub/cost-transport/docs/341-08-h-en.pdf (accessed 31/07/2017).

Eiffage (2014) Toward Ecological Civil Engineering. Eiffage, Paris, France, p. 23. See http:/www.developpementdurable.eiffage.com/ uploads/files/679d2dc67ac915c8112bfc611251a16d.pdf (accessed 31/ 07/2017).

Herder JE, Valentini A, Bellemain E et al. (2014) Environmental DNA - a Review of the Possible Applications for the Detection of (Invasive) Species. Stichting Ravon, Nijmegen, the Netherlands, Report 2013-
104. See https://www.researchgate.net/publication/283267157 (accessed 07/08/2017).

IUCN (International Union for Conservation of Nature) (2010) Made in Countdown 2010. IUCN, Gland, Switzerland, pp. 14-15. See http:// www.countdown2010.net/year-biodiversity/what-can-you-do/made-incountdown-2010 (accessed 31/07/2017).

IUCN (2016) IUCN Policy on Biodiversity Offsets. IUCN, Gland, Switzerland. See https://www.iucn.org/sites/dev/files/import/downloads/iucn biodiversity_offsets_policy_jan_29_2016.pdf (accessed 31/07/2017).

Quétier F, Régnery B and Levrel $\mathrm{H}$ (2014) No net loss of biodiversity or paper offsets? A critical review of the French no net loss policy. Environmental Science \& Policy 38: 120-131, http://dx.doi.org/10. 1016/j.envsci.2013.11.009.

RF (République française) (2006) Loi n 2006-1772 du 30 décembre 2006 sur l'eau et les milieux aquatiques (1): Préservation des ressources en eau et des milieux aquatiques. Journal Officiel - Lois et Décrets 0303 See https://www.legifrance.gouv.fr/affichTexte.do?cidTexte $=$ tpLEGITEXT000006055130\&dateTexte=vig $($ accessed 04/09/2017; in French).

SNCF (Société Nationale des Chemins de fer Français) (2010) First Railway Carbon Footprint Study. SNCF, Paris, France. See http:// www.evenement.sncf.com/sncf/tgv/tgv rhin rhone/ FirstRailwayCarbonFootprintStudy.html (accessed 31/07/2017). SNCF Réseau (2017) Atlantic 2017: the Rush to the West of France. SNCF Réseau, Dijon, France. See https:/www.sncf-reseau.fr/en/railprojects-worksites/france-europe/atlantic-2017 (accessed 31/07/2017).

UIC (International Union of Railways) (2016) Carbon Footprint of Railway Infrastructures. UIC, Paris, France, pp. 28-29. See http://uic. org/IMG/pdf/carbon_footprint_of_railway_infrastructure.pdf (accessed 31/07/2017)

\section{How can you contribute?}

To discuss this paper, please email up to 500 words to the editor at journals@ice.org.uk. Your contribution will be forwarded to the author(s) for a reply and, if considered appropriate by the editorial board, it will be published as discussion in a future issue of the journal.

Proceedings journals rely entirely on contributions from the civil engineering profession (and allied disciplines). Information about how to email your paper online is available at www.icevirtuallibrary.com/page/authors, where you will also find detailed author guidelines. 